\title{
Cities, states, trust, and rule: new departures from the work of Charles Tilly
}

\author{
Michael Hanagan • Chris Tilly
}

Published online: 27 March 2010

(C) The Author(s) 2010. This article is published with open access at Springerlink.com

\begin{abstract}
In the light of his essay "Cities, States and Trust Networks," contributors to this collection were asked to consider ways of building on or departing from the late Charles Tilly's work. The authors in this collection addressed four major themes: (1) historicism and historical legacies, (2) trust networks and commitment, (3) citystate relations, and (4) democracy and inequality. Authors concentrating on historicism examined how, despite unanticipated consequences, social action nonetheless produced systematic, durable, social structures; they particularly focused on processes of identity formation and cultural reproduction. In regard to trust networks, contributors discovered a striking variety of forms and relationships and they investigated their origins and their relationship to institutions and culture. Looking at city-state relations, authors uncovered the richness and intricacy of the ties linking cities and states and showed that city-state relations were important not simply in terms of the autonomy or dependence of mutual ties, but also in the quality of these relationships. Besides the ties between cities and states other authors sought to focus on empires and wondered about the degree to which empire formation involved similar processes as state formation. Several authors developed this theme. Authors pursuing themes of democracy and inequality stressed how changes in citizenship and the expansion of parliamentary democratic forms might have complicated effects. The relationship between democracy and inequality was mediated by elites and institutions. Democracy constrained inequality but inequality also constrained democracy. Increased state capacity might enable states to remedy old inequities but it might also allow them to perpetrate new ones. The authors' varied responses suggest promising directions for research on cities, states, and trust networks.
\end{abstract}

\footnotetext{
M. Hanagan $(\square)$

Vassar College, Poughkeepsie, NY, USA

e-mail: mihanagan@vassar.edu

C. Tilly

Institute for Research on Labor and Employment, University of California Los Angeles, Los Angeles, CA, USA

e-mail: chris_tilly@irle.ucla.edu
} 
Preoccupation with the power of the state, with the social organization of cities, with the connections between the two, and with the implications of both for the lives of ordinary people, dates back to the origins of social science. The late Charles Tilly shared these preoccupations. His attention to state-making (e.g., Tilly 1985, 1990), to states' roles in repression and contention (e.g., Tilly 1986; McAdam et al. 2001), and to the determinants of democratization and de-democratization (e.g., Tilly 2005, 2007) are well known. But Tilly also returned repeatedly to examination of cities, in early work as an urban sociologist (e.g., Tilly 1965, 1974), in mid-career reflections (Stave 1998; Tilly 1998), and in his lifelong work on revolution, collective violence, and contention that scrutinized the urban context of many such activities.

When Charles Tilly died he left a manuscript devoted to the topic of "Cities and States in World History." We possess only one completed chapter of this book, his introductory essay, "Cities, States and Trust Networks." The issues this essay raises concerning relations among cities, states, politics, and trust networks, touch on themes long central to his work, but Tilly's growing interest in world history also makes it a new departure. We decided to use this essay as an opportunity to consider Charles Tilly's work. To this end, we invited a number of distinguished scholars, some of whom knew Tilly personally, others who were only familiar with his work, to consider ways in which his work might serve as a starting point for new research and fresh investigations and to show how this might be done through empirical studies. We recruited a group varied in discipline (geography, history, political science, sociology, urban planning), as well as in geographic and temporal focus. We supplied contributors with a copy of Tilly's essay, "Cities, States and Trust Networks" (published as the first article in this collection) as well as a copy of his seminal 1996 article, "What Good is Urban History?" but we did not require that contributors address any specific themes. It seems fitting to publish this collection in Theory and Society, a theoretically-informed journal of social processes, where Tilly was an editor for 25 years.

Our approach to this special double-issue of has not been so much to celebrate Tilly's work, though of course we do, as to use it as a point of departure. For some contributors, his work serves as an inspiration, others see Tilly's work more critically. But both inspiration and criticism are ways of acknowledging importance and also of advancing research. The essays that we received show the variety of Charles Tilly's influence. They show scholars building on Tilly's work, but also extending, revising, and questioning it, as well as striking out in new directions. At least four major themes emerged from these essays and in this introduction we shall discuss them briefly. The four themes are: (1) historicism and historical legacies, (2) trust networks and commitment, (3) city-state relations, and (4) democracy and inequality.

Most of the papers touch on more than one of these themes. Consequently, we have built a little repetition into this introduction in an attempt to do justice to the authors' multi-faceted analyses. We trust the resulting redundancy enlightens more than it stultifies.

\section{Historicism and historical legacies: contingency and endurance}

Charles Tilly intended his book on world history to discuss big structures and large processes by means of huge comparisons. Working to scale, our introduction begins 
with a brief discussion of an enormous methodological issue, that of historicism. Many of our contributors discussed historicism although not everyone agreed about its utility.

Tilly was known as a student of state formation who studied the emergence of modern, consolidated states and the growth of cities in a historicist vein. He defined historicism as the idea that "past social relations and their residues-material, ideological, and otherwise - constrain present social relations, and consequently constrain their products as well" (Tilly 1996). As Marcel van der Linden points out in this issue, Tilly agreed with the sociologist Robert Merton that historicist approaches were necessary because even the most rational and considered actions often yielded "unanticipated consequences." Actions often resulted in outcomes far different than their initiators expected. But Tilly also raised a related question. How, despite unanticipated consequences, did social action nonetheless produce systematic, durable, social structures? To answer this question, he forged a chain from trial and error to self-correction to incremental but systematic and ultimately durable changes in social relations and culture (Tilly 1996, p.709).

Tilly's emphasis on structure and contingency gets at the heart of any sophisticated historicist argument. Contingency is a powerful force. Small events can have wildly disproportionate outcomes. A degree or so fall in average temperature led to the abandonment of the Greenland colony, closing the Scandinavian route to North America in the fourteenth century. Two centuries later, in a warmer Atlantic, an Italian seaman sailing for Spain charted a new route to North America. It might be diverting to ask what would have happened if Norwegians had settled North America in 1350, but the ramifications are so great that the game loses much of its interest. (Fagan 1999)

But what role does this leave for structure? The relationship between structure and contingency has been hotly debated with regard to class. Some, such as Karl Marx (1910), have argued that class consciousness is an inevitable product of worker exploitation and that the working class will sooner or later become a "class for itself." In contrast, E.P. Thompson (1964) depicted class formation as a conjuncturally specific set of historical events. Echoing this viewpoint, Marxist Eric Hobsbawm colorfully commented that class consciousness is not like a bus, in that if you miss the first one you can catch the next. Enduring structures emerge from contingent origins. Social historian Tilly, of course, lined up with this latter view.

Numerous essays in this collection follow Tilly in walking the tightrope between contingency and structure, balancing Merton's emphasis on unintended consequences with Marx's interest in durable structures. Marcel van der Linden's essay is a good starting point for our discussion of historicism. According to van der Linden, in response to the power of the abolitionist movement the British government introduced a series of practices to combat slavery that were later, in a stunning turn of events, used to facilitate British imperialist domination in Africa. Over time, responses to the durable inequality of slavery created other structures designed to dismantle it. After the 1807 passage of the "Act for the Abolition of the Slave Trade," to respond to slavers' subterfuges British authorities pursued one strategy after another, each proved fruitless and each increased British control in West and South Africa, moving Britain down a contingent path toward new structures of domination. In retrospect, this gradual penetration and control over large portions of the African continent seems to have led almost inevitably to the expansion of imperialism on the African continent in the $1880 \mathrm{~s}$. But this is to ignore the 
intent of most of the staunch abolitionists who had initiated and long sustained the process of British expansion into Africa. In 1807 no one could have foreseen the partition of Africa in the 1880 s.

Ariel Salzmann likewise shows how contingent actions can harden into durable structures - in this case focusing on cultural understandings, religious communities and institutions. Salzmann compares the treatment of Jewish minorities in Western Europe with that of Jews and Christians in the Islamic world between $600 \mathrm{CE}$ and 1914 CE. She asks: why were entire Jewish and Muslim communities expelled from Western nations while Christian and Jewish communities were successfully integrated into a Muslim state, without being completely absorbed?

Salzmann's answer points to the historically contingent roots of sturdy structures of inclusion and exclusion. At least part of her argument hinges on the unique and never-to-be repeated historical context in which social compacts were established in the societies conquered by the Arabs in the seventh and early eighth centuries. While the results of these compacts were quickly embedded in institutions and laws, she argues that such compacts, when reinforced in concrete institutions, established broad cultural consensuses that would endure in the Islamic world for centuries to come. Accepted by the Arab conquerors, Jewish communities were able to integrate themselves into Islamic society in a variety of contexts. In contrast, she argues that Jews came late to Western Christendom, arriving at a point when some niches typically filled by Jews in the Muslim world - literate bureaucrats, capital providers, and people with contacts throughout the Mediterranean - had already been filled by Christian clergymen who regarded the Jews as rivals. Never strong, the position of Jewish minorities in Europe weakened, weakness opened them up to plunder and thus to further weakening - and so on in an ever-descending spiral. European Jews found themselves increasingly confined to ghettos that imposed occupational limitations on them and made it more difficult for them to integrate into the larger community than for their compatriots living in the Muslim world. It was a relatively short step to expulsion.

Several essays take a closer look at the process of identity construction so critical to the maintenance of durable social structures. A key element of any historicist argument concerns the mechanisms for both the spawning of innovation and the reproduction of tradition, and identity formation can bridge the two. Wim Blockmans's contribution shows how after $1000 \mathrm{CE}$ a new mercantile class emerged in growing cities to assume civic and commercial responsibilities that had disappeared after Roman emperors and Germanic kings had dropped the reins of government. Originally stepping in to perform occasional commercial chores, merchants gradually expanded their competence and became conscious agents of urban capitalism. Contingent interventions accreted into structural roles. Nine hundred years later, Elisabeth Clemens also shows how business communities - in this case in urban America-organized themselves into collective bodies and forged distinctive identities. But in this case the typical identity was a political one basing itself in the broad middle classes and using charity to sustain a claim to represent the general good. Although US urban elites stumbled onto this identity through experimentation, they developed a vested interest in the role and fiercely defended it. Interestingly, at the outer end of both Blockmans's and Clemens's accounts, we see these structures being displaced-by formalized state institutions and national charities, respectively. We further examine that transition below. 
Hwa-ji Shin's article on the formation of Japanese identity in the first half of the twentieth century focuses on a national identity that persists to this day. In so doing, her work helps explain the mechanisms that contributed to the replication of inequality for Korean migrants over decades. She argues that the particular exclusionary identity that appeared in post 1945 Japan must be understood as linked to official efforts to deal with the legacies of imperialism. According to Shin, modern Japanese identity-with its focus on the ethnic homogeneity of the homeland - was an image produced and sustained by the post-World War II collapse of empire. In the era of imperial expansion that preceded World War II, Japanese imperialists had encouraged the idea of pan-Asian identity, promoting a front of Asian peoples united by a common culture against Caucasian imperialist domination. On these terms, hundreds of thousands of Korean workers entered Japan to labor in industry. The end of the war and the loss of empire created a "Korean question" in Japan. Politicians sought to deal with restive Korean workers, some suspected of Communist sympathies; Koreans occupied jobs seen as rightly belonging to Japanese colonists fleeing advancing Chinese armies. Japanese bureaucrats responded by reinventing Japanese identity to include only those within the nation sharing a homogenous cultural identity, consigning Koreans to deportation or semi-clandestine assimilation and inferior status in the 1940s and 1950s.

In the 1980s and 1990s, years of Japanese boom and bust, this same policy of deportation, discrimination, and denial of citizenship to Koreans and newer immigrant groups was pursued unreflectively. Policy from the 1950s was re-implemented without debate or discussion, according to Shin, in large part because a bureaucracy that imposed the 1950 s policy was still intact in the 1980s and applied the very policies it had initiated then.

Miguel Angel Centeno and Elaine Enriquez consider far more broadly the transition between empire and post-imperial state(s). How does the persistence of imperial legacies shape successor states and former colonies? Centeno and Enriquez trace the origins of their essay to their search for some area of scholarly interest "under-explored" by Tilly. Looking at empire, they sought to explore ways in which he "may have approached the sociological phenomenon of empire ... using his characteristic forms of inquiry and interest to suggest links between imperial phenomena and national state outcomes." Like Tilly, Centeno and Enriquez seek "to develop a discourse around state transformation."

Centeno and Enriquez advance a list of propositions about the impact of imperial legacies that draws on the discourse that Tilly developed in analyzing the consolidated state. The concern for warfare, money, the state's ability to extract it, and the role of capital in politics are central to Centeno and Enriquez's analysis of empire formation as they were central to Tilly's study of state formation. Their propositions neatly embody the tension between structure and contingency. Each proposition starts by stating an expected legacy of empire, but each such statement is followed by an exception to the rule: "Under some circumstances, however...." Thus, Centeno and Enriquez argue that empires generate complex administrative structures that are inherited by post-imperial states-except when they rely on indirect rule that retards the development of bureaucracy; that empires "require efficient capital-extraction systems, which lead to well-developed state fiscal structures"- except when they prove so lucrative that they obviate the need for tax collection; and so on (in these cases, Spain falls into the "exceptional" category). 
Setting aside the theme of contingency and structure, the imperial context discussed by van der Linden, Shin, and Centeno and Enriquez raises questions of special interest to historians (Centeno 2003). What are the forces in empire formation and how similar is the process of empire formation to that of the consolidated state formation so thoroughly studied by Tilly? They push us to look at the character of decision-making under conditions of multiple sovereignty and at the question of how consolidated states develop from transnational polities, in situations of differently empowered polities, governed by local rulers with supreme power within their domain but subordinated to an often distant metropole.

Centeno and Enriquez present an effort to adopt Tilly's approach to the study of empire but we might also consider the limitations of his approach for the study of empire. Tilly's analysis of state formation focused on the competitive state system in which the threat of war forced every country to fight to survive. It was a world in which a change in the balance of power was sufficient justification for a declaration of war. But as Immanuel Wallerstein (1974, pp. 16-17) pointed out, such a world was atypical and infrequent in world history; empires have been more common (Wallerstein 1974, pp. 16-17). As Karen Barkey has argued recently (Barkey 2008, p. 14), empires were often based not just on force but also on administrative and political flexibility as well as on constant negotiation with potential troublemakers. Empire-ruled worlds were not worlds in which states continually stretched every last resource to engage in war.

Indeed, one legacy of empire might be its generation of less cutthroat state systems among the nations emerging from imperial dominions. Both the Spanish empire and the British empire as they sloughed off the raiments of empire left relatively non-competitive state systems in their place among their heirs in Latin America and among the thirteen North American colonies.

Of course, historicist approaches are only one set of weapons in the quiver of social scientists and historians. Not everyone in this collection agrees, either in whole or in part, with historicist approaches. Edward Soja criticizes the foregrounding of time as against an emphasis on spatial analysis. Beginning like Tilly in the era of the Neolithic revolution in the Near East, he thoughtfully criticizes Tilly's definition of the city. In his essay in this collection, Tilly defines the city as a "human settlements combining significantly denser resident population than their surrounding territories, differentiation, and inequality within the resident populations, some central authority, and nodal locations within existing networks of communication." Soja, however, argues the first cities were formed by egalitarian bands of hunters and gatherers, preceding inequality and authority but laying the foundations for their later development. Soja criticizes Tilly's definition for teleologically combining urbanization and state formation, distracting us from understanding how urban population concentration in itself has propelled social change.

Taken together, discussions of historicity in this collection offer a rich grab-bag of ideas. They show us repeatedly how path-dependent contingency shapes enduring structures - structures that may then be reshaped or shattered by a later wave of historically contingent events. The authors highlight identity formation as one key step in processes connecting contingent human actions and choices with persistent social realities. Several of them spotlight empires, exploring worlds that parallel the world of Westphalian states that drew most of Charles Tilly's attention, and probing 
the applicability of Tilly's concepts in these parallel worlds. And one article, that of Edward Soja, offers an explicit, spirited challenge to historicism, proposing instead a "geohistory" that puts spatial differentiation at the center of social change.

\section{Trust networks and commitment}

Common to the world of empires and consolidated states and binding together many different kinds of political and social structure are the links that Tilly defined as trust networks. Trust networks are "major, long-term, collective enterprises at risk to the malfeasance of others" (Tilly 2005, p. 4). They can undertake responsibilities sometimes performed by states; they may support and reinforce state structures; and they are often a tempting target for predatory states seeking resources. Reinforcing and elaborating Tilly's idea of the trust network is his emphasis on commitment. According to Tilly, trust networks are "commitment-maintaining" connections expressed in "common languages, secret lore, distinctive communication lines: They take the form of "shared religion or ethnicity, trading ties, work-generated solidarities, communities of taste." Commitment is reproduced by "birth within households or by person-by-person enlistment."

Tilly's definitions of trust networks and commitment were capacious, including many different types of social and cultural formations. Contributors to this collection provide a striking variety of ways of thinking about trust networks and using them in empirical research. Their articles address three important questions emerging from Tilly's work.

First, how are trust networks formed? Tilly devoted a good deal of attention to the operation and dissolution of trust networks but relatively little space to the manner of their creation. Taking a medieval and early modern perspective, Wim Blockmans shows us trust networks that involve multi-stranded relations between individuals and groups. They may start with simple relations, single strands, maybe only casual encounters, but as the number and variety of ties increase they bring individuals more intimately together. Blockmans's medieval European trust networks were the product of face-to-face encounters at markets and intermarriage among mercantile families, which compounded into new networks within and between cities. As cities grew, merchants took responsibility for providing security and guaranteeing financial transactions, activities earlier undertaken by states. Between 1000 and 1600, merchants in the great commercial belt from the southern Low Countries to northern Italy constructed networks: to facilitate travel, to administer growing cities, to organize confraternities and guilds, to form joint-stock corporations for long-distance commercial transaction, to participate in urban political factions, and to provide a literate and secular officialdom to serve expanding states Over time they created a mercantile identity not only within the community but within an entire trading network. Each of these projects intertwined with the others and strengthened commercial identities.

As we have noted above, where Blockmans focuses on trust networks as based on personal contact, Elisabeth Clemens shows us middle-class reformers working to construct an institutionalized trust network that would capture civic consciousness for the emerging US urban elites. Such an institution fused personal ties and institutional structure. In the early twentieth century, laissez-faire advocates decried 
what they saw as the corruption of charitable giving. They mocked what they believed to be the crowds of skillful shirkers who feigned illness or incapacity. One laissez-faire solution was to recruit solid middle-class volunteers, often women, who were charged with the task of sorting out charities and deciding which ones were worthy of sponsorship and which were not. Decision-makers, largely members of the elites, were recruited via networks based on informal contacts and reputation. Over time, this organized volunteerism created a network of institutions. Such a system was exemplified in the Community Chests of the 1920s, which played an important role in many communities. Essentially the Community Chest, predecessor of the modern United Way, was an organization of organizations.

Hwa-Ji Shin shows us the origins and impact of another trust network - that of Japanese imperial officers posted in the colonies, where they formed ties of mutual aid among the few Japanese. What renders this network so significant is that its members became responsible for the formulation of a Japanese citizenship policy crucial to national identity formation. As we have seen, in the wake of imperial collapse a small part of the Japanese bureaucracy, the Immigration Bureau imposed a narrow definition of Japanese identity on a defeated population, and later reconstituted itself to impose this definition even in the very different climate of the 1980s and 1990s. Like the trust network described by Clemens this one was based on longstanding ties. Where Clemens's network built new institutions, Shin's built on shared location within a pre-existing institution, the Japanese imperial state.

Diane Davis presents yet another case of trust network construction and expansion, in which localized gangs follow the paths of drug networks and other criminal activity to escape local confines and become a transnational organization. Contemporary Latin American gangs initially formed in urban environments that offered comfortable rewards for criminals and little danger of repression from semi-powerless and often corrupt, local authorities. The evolution of gang life follows the migration networks of these young men, for example jumping from El Salvador and Guatemala to Mexico City and Los Angeles and recruiting in each location. Returnees deported or fleeing police in foreign countries help to maintain the two way connections across this transnational network.

In a second question about trust networks, many of our contributors follow Tilly in asking about the conditions under which trust networks are segregated and entirely distinct from states and under what conditions are they integrated into states. Blockmans presents a classic case of the dissolution of segregated trust networks by predatory rulers. Blockmans's trust networks ended as the power of the European state increased and, he argues, as the scale of human communication and interaction reached its limits. As cities grew, financial trust networks split and factionalized. Mercantile communities outgrew their face-to face informality and, lacking communicative technologies to keep in sustained contact with their fellows, were forced to institutionalize. But institutionalization further encouraged factionalism and made trust networks sitting ducks that could easily be incorporated by growing states that craved their resources, both in money and in personnel. Desperate for public servants who were literate, informed, and secular, rulers recruited state officials from the urban commercial classes, freeing states from dependence on the church.

Although integration of trust networks into the state may expand state capacity, it may actually destabilize the state. The fractiousness of the urban elites in the 
medieval and early modern city is mentioned by Blockmans as one of the reasons for the collapse of mercantile polities. Charles Tilly argued that capital-intensive states were characteristically unstable. The reason for this instability, Sidney Tarrow has posited, is precisely that mercantile interests were integrated into states in a way that favored the perpetuation of special interests and discouraged any concern for the commonweal. Following the chain of city states and autonomous regions that ran down the center of Western Europe from Amsterdam to Florence, the phenomenon of bitter urban rivalry and suicidal factionalism was most prominent in the south. Taking the case of Florence, Tarrow (2004) shows that wars were undertaken as interest-earning investments; government decisions were often made by short-lived pacts of private interests; and underlying all decision-making was a fear of popular revolt. In such a polity, it was all too easy to make foreign policy decisions by looking at the accounts' book. Penny-wise and pound-foolish merchants refused to invest in personally unprofitable wars even if they redounded to the long-term good of the commune. Complementing Blockmans's account of the capture of commercial trust networks by the state, Tarrow reinterprets the event as the capture of the state by commercial trust networks.

Clemens provides a dramatic example of the integration of trust networks into government: that of Theodore Roosevelt's tapping a nearly moribund Red Cross to mobilize national resources to help an earthquake-ravaged San Francisco. Rather than create a federal authority to perform this task, the US president encouraged the growth of an independent, private volunteer organization. Looking over the longer historical sweep, what is remarkable is that unlike European monarchs in the early modern period, Roosevelt did not view trust networks as a threat to state power nor did he seek to seize their resources. Instead he supported the growth of independent volunteerism as a way of mobilizing reformers for national purposes. Although Clemens does not discuss the situation in her brief article, it is worth recalling that the president's enthusiasm for voluntary organization was partial. He did not try to extend rights to radical groups such as the Industrial Workers of the World nor endorse the civil rights agenda of the Niagara Movement. He did try to promote a middle class, private volunteer organization, probably for the same reasons that that urban elites supported the Community Chest: because it brought middle class men and women into government to pursue universally-approved tasks.

The Latin American polities described by Diane Davis and Carmenza Gallo at first glance seem to show a contrary pattern of separation and in some cases outright hostility between trust networks and the state. In Davis's Mexico and Gallo's Colombia, despite regular and competitive elections and other trappings of democracy, groups of armed men with no state sanction-gangs, paramilitary squads, private security forces, vigilantes - circulate more or less freely, defending the interests of a variety of trust networks. The model looks more like warlordism than what we think of as modern governance. But upon closer examination, manifold links emerge between the state and the freelancers. The armed groups' free circulation is itself premised on buying off or otherwise enlisting the support of police, military, and government officials. Criminal enterprises may enjoy support from elites or even broader publics if they provide economic benefits and physical security. So while official government discourse deplores extrastatal violence, invariably shadowy ties connect the state with the perpetrators of that violence. 
Businessmen, middle class volunteers, and gangsters may belong to trust networks but so do members of mutual aid societies. Smita Srinivas's discussion of welfare states underlines one of the enduring problems of late industrializing states. By absorbing welfare trust networks, the states could greatly increase the commitment and identity of the citizens, as well as pooling risks more broadly. Yet the cost of such integration is so substantial that only partial integration is possible. As a result, the injured, sick, aged, and incapacitated remain dependent on particularistic institutions, reinforcing their loyalty to these non-state groups. She points out that in European history national welfare states developed out of and incorporated local institutions. The modern Indian state has established a welfare system based on compulsory work-place insurance, but given the relatively small formal sector, this scheme's research is quite limited. Meanwhile, the state has proven unable or unwilling to integrate myriad local relief mechanisms based on community, caste, language, religion and jati (occupational/caste/clan categories peculiar to Indian society).

A variant of the question about state-trust network integration inquires: under what circumstances do trust networks engage in collective political action? For most of their long history most trust networks have tried to remain outside politics for fear that political engagement would attract the attention of predatory rulers. Tilly noted that democratic governance provides a climate in which they could participate in political action. Of course, as Gallo points out, even in regimes with competitive parties and regular elections, trust networks are not likely to enter politics in force when there is every chance that critics of the elite will be assassinated.

A less violent version of democracy offers a more encouraging environment for trust network mobilization, but that does not ensure that government will incorporate the networks. Patrick Heller and Peter Evans depict democratic governments that exclude trust networks from meaningful participation. Their contribution, which we discuss in more detail under the heading of city-state relations, compares Brazil, India, and South Africa, three stable democratic polities. In all three cases, vibrant local civic and social movement organizations are active in politics. But top-down governance in India and South Africa locks out such organizations. The contrary case is Brazil, where integration of local grassroots networks is widespread due to the construction of decentralizing institutions and political traditions.

A third question shifts the focus from the trust networks' relationship with politics and the state, to their relationship with culture and society. How can we relate trust networks with the broad feelings that emerge from citizenship or from other forms of broad-scale allegiance? One such effort to relate trust networks to the broader society that retains the integrity of both is that of Ariel Salzmann. Jews, who were a minority in both Western Europe and the Muslim world, present a classic example of a trust network. They shared a common religion, and often spoke a second language common to the group. In a world where charitable giving was monopolized by religious institutions, Jews had to develop their own institutions to help fellow believers. Christian and Muslim minorities formed similar networks.

However, Salzmann emphasizes not the trust networks themselves, but rather the context in which these networks functioned. According to Salzmann, the founding compact of the Muslim state, the negotiations and bargaining between conquered and conquerors, decreed toleration and subordination for Jewish and Christian 
communities. This founding understanding was shaped by the existence at the time of Christian majorities in the Near Eastern and North African lands that the Arabs had conquered. As noted above, the "founding compact" was initially a cultural construction, although soon reinforced by laws about property and community government and occasionally supported by spurious historical documents. Together these shared understandings and legal and social institutions that emerged from them created an interlocking social and political world.

Salzmann takes Tilly's argument in a new direction. Not only does the construction of the trust network itself include a large cultural component, so do the ties relating it to the larger society. The picture that Salzmann draws is of Christians, Jews and Muslims in Islamic society sharing a vision of appropriate roles and relationships. Trust networks and commitment exist in a larger cultural context.

In Salzmann's account, a widely shared understanding creates a social place for "outsider" trust networks. But let us return for a moment to Shin's postwar Japan. Here an "insider" network (made up of those former "outsiders" in the colonies they administered) enacted policy decisions that resonated with popular fears and suspicions of Koreans and quite literally shaped a new Japanese culture and identity. Here culture was not just a context for the functioning of trust networks, but a consequence of that functioning. (One suspects there is yet another trust network story to be told about how Koreans banded together for mutual support in postwar Japan.)

One of the difficulties with Tilly's idea of the trust network is the great variation among such networks. On the one hand, trust networks include relatively small mercantile networks based on personal contact and, on the other, they include Indian castes and religious groups embracing hundreds of millions. They include "outsider" networks far from the centers of power, which particularly attracted Tilly's attention, but as Blockmans, Clemens, and Shin describe, they also include "insider" networks of well positioned elites. The wide-ranging essays making up this collection span a large slice of this variation. By examining network origins and the degree and nature of network-state and network-society linkages across this diverse spectrum, they teach us about variation, but also help make the case for common elements in trust networks.

\section{City-state relations}

Charles Tilly's essay in this collection poses the question of "how our incredibly connected world emerged from the once-fragmented relations between cities, states and trust networks." Tilly was interested in more than the degree of world integration, he was also interested in the character of that integration. In the concluding sections of his article, he asks about power relations between cities and states and about the integration of cities into states (as well as the question we just addressed, about the extent to which trust networks have been integrated into urban and national state structures).

The essays in this collection respond to this challenge in two related ways. First, they address the importance of scale in the relationship between states ruling larger territories and cities occupying smaller subsets of those territories. Second, they examine the political articulation between cities and states, on the whole making a stronger case for wide variation in that articulation than for a modal or tendential pattern. 
In Charles Tilly's formulation, the rise of the nation-state is a triumph of scale. Tilly's Fig. 1 (see Charles Tilly article in this collection) summarizes the direction of evolution of city-state relations with a large arrow pointing toward integration of cities and states, and toward state domination of that integrated complex. Despite the continued existence of some city-states and of cities that evade the writ of their national states, Tilly argues that over the long sweep of history power has shifted to nation-states. Wim Blockmans adds historical detail to Tilly's schematic proposition, showing the importance of increasing urban scale in precipitating a greater state role. As we have described, Blockmans documents that in the early centuries of the last millennium, to a large extent merchant trust networks organized life in European cities. But as cities grew, they outstripped the ability of trust networks to govern them, and increasingly urban actors established and expanded institutional state structures. We can see a Tillyan arrow pointing from city-state segregation to integration. In this process, territorial rulers often intervened and helped build local states accountable to national onesgenerating a second Tillyan arrow from city dominance to state dominance.

But before we accept this account of scaling-up of power, we must take account of an elaboration and a riposte that also crop up in this set of articles. The elaboration is empire. As noted above, Marcel van der Linden, Ariel Salzmann, and Hwa-Ji Shin remind us that over much of the populated territory of the world, over most of human history, empires rather than nation-states represented the dominant form and scale of territorial power. A unidirectional arrow from autonomous cities to centralized states may offer a good approximation of the earliest centuries of human history, as cities gave way to empires, and also of the last thousand years of European history. But in between, elsewhere, and even within recent European history many empires have crumbled - at times displaced by competing empires in a scale-preserving process, but at other times scaling down into localized states or even cities. Today, the empires that survive are the ones that have successfully incorporated hinterlands into a unified nation-state, such as Brazil, China, India, Russia, and the United States (though ongoing struggles by Chechens, Kashmiris, Puerto Ricans, Tibetans, and Yanomami remind us that such integration is not always definitive). In place of a single scaling-up arrow, it would be plausible to argue that the global trend has been scaling up to empire followed by scaling down to the nation-state. At a minimum, the "many a wiggle" Tilly acknowledges in the process of centralization and integration merit closer examination.

Beyond the elaboration on empire, there is an even more incendiary riposte. Edward Soja ignites the blaze by throwing three bombs. Soja's bunker-buster, as we have observed, is a thorough-going reinterpretation of world history. "There may indeed be a trend toward increasing state vs. urban power," he allows, but this misses the main point: "cities and the urbanization process have provided perhaps the most important generative force behind every major breakthrough in human geohistory" (geohistory, recall, is Soja's term for a reconceptualization of human experience that restores space to a rightful equal status with time). States may have the power, but cities have the spark that has repeatedly generated social, technological, and cultural advances. According to Soja, a one-sided focus on change over time at the expense of variation across space has blinded not only Tilly but most social scientists and historians to this regularity.

Soja's other two projectiles are more modest in scope. His second blast, also previewed above, posits that cities preceded centralized authority of any kind. His 
evidence is the ruins of Jericho in modern-day Jordan, Çatalhöyük in Turkey, and other ancient locales in the region, dense and differentiated settlements with no archeological evidence of hierarchy or authority that predate by thousands of years cities showing the residues of state power. As Soja notes, Tilly nods toward these settlements but concludes that they are not cities precisely because his definition, following much historical convention, includes "some central authority." So Soja's conclusion directly contradicts Tilly. Ironically, however, at the same time it reinforces Tilly's arrow. If urbanization preceded the creation of even a local state by thousands of years, that implies a Tillyan shift toward integration of cities and states over time.

But Soja's third missile flips Tilly's arrow by introducing the concepts of rescaling and regionalization. In the last three decades, Soja argues, globalization and the flexibility of economic processes have shaken up established hierarchies of scale, diminishing the significance of the national state and increasing the power and prominence of both multinational regional entities (such as trade blocs) and sub-national metropolitan regions. Although Soja stops short of arguing that cities are gaining power at the expense of states, he does insist that metropolises are becoming more important and that conventional conceptions of the geographic and power structures of nations are becoming obsolete.

Diane Davis's contribution illustrates the process of rescaling. As we have recounted, she describes how, in countries like Mexico and Brazil, non-state actors, most notably organized crime groups involved in the drug trade, bypass the state by forging direct economic connections between their city-based organizations and the global economy and by creating their own groups of armed enforcers. The result is "sub-national and transnational communities of allegiance," newly flourishing illicit trust networks like the Salvadoran-origin Mara Salvatrucha and the Mexican-origin La Familia Michoacana that use global-scale economic muscle to challenge the state on its home turf of monopoly of repressive power.

Thus, this collection's discussion of scale in city-state relations shapes up to be something of a brawling debate. Tilly and Blockmans tell a familiar story of the scaling up of the locus of authority. But empire-gazers van der Linden, Salzmann, and Shin suggest that the scale of power has followed a more zigzag path. Urbanists Davis and Soja point to contemporary rescaling processes that shift key activities and networks both above and below the national level. And Soja goes farther to preach outright subversion of conventional state-centered historicism.

Turning to the political articulation between cities and states, the contributions offer up some debate as well, but rather more exploration of the dimensions of variation in that articulation. Few giant arrows here; rather, primarily a set of historically grounded maps of many possible relations between city and national state.

Peter Marcuse does erect a large arrow. It points from the national and international conflict between dominant and subordinate classes, to the reproduction of that conflictive interface on the urban scale. But Marcuse points out that this central conflict only goes part of the way to explaining urban form and processes. Along with a logic of domination, urban space is governed by a functional logic based on which land uses it is efficient to co-locate and to separate. Functional spatial logic dictates that housing should be located near shopping facilities, and far from slaughter-houses and chemical plants. A cultural logic also shapes urban form: ethnic enclaves and gay zones may result in part from exclusion, but in large part from self-selection. 
Patrick Heller and Peter Evans parse the link between city and national state in quite a different way. Implicitly challenging Marcuse's arrow, they point out that despite similar progressive, populist regimes, South Africa and Brazil manifest utterly different state-city relations: in the former case top-down, in the latter case far more decentralized and bottom-up. Indeed, their second case gainsays Tilly's arrow toward greater national state dominance as well, since Brazil's urban empowerment is new, with roots in a recent social movement upsurge and a new constitution. More broadly, Heller and Evans problematize the relationship between national and local democracy, and thus between national-level democracy and local lived relations of inequality, based on a comparison of cities in India, South Africa, and Brazil. They conclude that in India and South Africa, national-level democratic impulses have been channeled into top-down, technocratic reforms that constrain local autonomy, ultimately compelling redistribution-minded national governments to form alliances with entrenched local political machines, freezing local inequalities in place. They approvingly cite Arjun Appadurai's (2002) phrase "citizens without cities" to capture this juxtaposition of national democracy with local exclusion. In Brazil, in contrast, decentralization and institutionalization of participatory processes have forged a virtuous circle between national democracy and local democracy fueled by social movements, opening the way to successful assaults on categorical inequality. Heller and Evans's exercise bridges the theme of city-state relations and our final theme of linkages between democracy and inequality, and indeed the duo's ideas make another appearance in our discussion of that theme.

Smita Srinivas illuminates yet another axis of variation in city-state relations by tracing the differential development of social insurance schemes in early industrializing countries and late industrializers, with special attention to India. Research on early industrializers, especially in Europe, has led to a notion of a standard trajectory from localized mutual insurance systems based in affinities such as family, church, and community, to national-level, unified, government-run systems via processes of incorporation and displacement. Even in the early-industrializing category, Srinivas deconstructs this hypothetical trajectory in two ways. First, she distinguishes between insurance institutions based in place (residential location), work (labor force status), and work-place (employer provision of benefits). The US system, leaning heavily on employer-provided health and retirement benefits, looks quite different—and responds quite differently to a changing economic environment - than European systems with redistributive, government-guaranteed social insurance. Second, she points out that even among nations that ended up with similar systems, the historical trajectories varied widely: for instance, Britain accommodated residential mobility far earlier than nearby Holland. In the interim between community-based and national systems, a welter of "corporations" took up the slack, including "fraternities, mutual insurance guilds, universities, communes, military orders, and city-states."

Adding late industrializers to the mix yields even wider variation in the lines between local and national coverage, Srinivas demonstrates. Japanese universal health insurance, while in many ways resembling European systems, combines workplace-based coverage with national community-based health insurance rooted in community-level jyorei health programs. More typical of late industrializers, Srinivas argues, is the Indian case. As we summarized above, outside of islands of coverage the Indian state offloads the insurance function onto local institutions rather 
than incorporating or linking up with these institutions: "evolution remains stunted and local, never merging into any grand ocean of national solidarity and industrial welfare." For much of the Indian population, social insurance depends on localized organizations akin to medieval Europe's corporations rather than on national state-constructed rules.

Teleporting from modern Bangalore to a collection of early twentieth-century US cities, we observe through Elisabeth Clemens's eyes local urban elites grappling with yet another local-national dilemma: how could they retain control over organized charity (another "corporate" system for assisting those in need) in the face of federal government attempts to privilege national-level organizations? Whereas Srinivas primarily fingers a low-capacity national state for continued reliance on local welfare systems, Clemens points out that even within modern capitalism, turf-conscious local influential figures may also contest nationalization. This clash puts Theodore Roosevelt's designation of the national Red Cross as the organization responsible for relief efforts following the 1906 San Francisco fire and earthquake in a different perspective. As Clemens shows, far from welcoming this endorsement of private charitable initiative, Bay Area worthies scrambled to reverse the decision.

Clemens's story sheds light on two of our Big Arrows. It conforms with Charles Tilly's schema with regard to centralization, since we know the Rotary Club and the Community Chest (now the United Way) have in fact ceded ground to the Red Cross, nationally regulated systems of unemployment insurance and welfare, and FEMA. But it challenges Peter Marcuse's mapping of national interests onto local ones, reflecting in inverted fashion Heller and Evans's rejoinder. Heller and Evans show that when champions of the subaltern hold national government, their attempts to implement a redistributive program may, willy-nilly, contribute to disempowerment and marginalization of popular classes at the city level. Clemens adds that local ruling classes may resent and resist the centralizing impulses of their national-level counterpart.

On the relationship between cities and states, then, our authors have much to add to Charles Tilly's two-by-two diagram showing increased city-state integration and state dominance over cities. Some amplify his story by fleshing out historical detail. Others nuance it by showing continuing variation in the degree of integration and dominance. Still others challenge Tilly's summary by extending history backwards, forwards, or sideways to different regions.

\section{Democracy and inequality}

Not surprisingly, this set of articles about cities and states has a great deal to say about inequality and democracy and the relationship between the two. This is to be expected because Charles Tilly wrote extensively about those subjects (notably in Tilly 1998, 2007). Although Tilly's introduction to Cities and States in World History does not directly analyze democracy or inequality, its preoccupations with the locus and forms of power, and the importance of trust networks, echo themes in his writing on these topics. Equally importantly, inequality and democracy command attention in explorations of cities and states simply because they are issues of great current concern. In broad terms, the authors in this collection make three main points about democracy and inequality.

First, they point out that ex post redistribution is only a small part of how states act on inequality, and that in fact all rights are, to a greater or lesser extent, 
redistributive. Carmenza Gallo reminds us that democratic political rights, property rights, and civil rights all facilitate or bar various kinds of redistribution. Indeed, the very concept of "ex post" redistribution misleads because it posits a particular "state of nature" that in actuality includes many products of state action, such as a stable distribution of assets. Gallo goes beyond this observation to argue that it is more difficult to institute rights that are more directly redistributive (thus engendering opposition from vested interests) and that require a denser set of rules (and thus demand greater state capacity). Based on this framework, she hypothesizes that electoral democracy (limited redistributive implications, modest regulatory demands) should be easier to implant than civil rights (which require a denser net of state regulation for support) and especially property rights (highly distributive and high maintenance). She bolsters this argument with evidence from the recent history of Colombia, where electoral democracy thrives but property rights and civil rights to freedom of speech, assembly, and even freedom from violent attack have all weakened under assault from armed groups, often in concert with local elites.

Ariel Salzmann and Hwa-Ji Shin also join this conversation, affirming that citizenship itself is a crucial redistributive right. States typically set criteria for citizenship in ways that ratify pre-existing categorical inequality, for example discriminating based on ethnicity or national origin (Shin) or creed (Salzmann). This in turn conditions individuals' access to livelihood, rights to hold property, and even their right to continued residence within a nation-state's territory. Salzmann in particular traces a complex interplay between citizenship rights for minority religions and states' (redistributive) confiscation of their resources. Whereas in Muslim central Eurasia rulers taxed minorities for broad redistribution in a relatively stable arrangement, in the Christian West higher levels of state-sponsored plunder of Jews and Muslims undermined these groups' usefulness to national elites, with destabilizing consequences that often culminated in expulsion.

A second point emerging from these essays is that though democracy constrains the domination of capital, concentrations of capital also constrain the operation of democracy. Though stated in this way the point hardly seems contentious, in fact it significantly complicates the relation between democracy and inequality, as contrasting strands in this set of articles attest.

Let us trace this complicating trajectory. As a starting point, Patrick Heller and Peter Evans offer a first-order statement of the relation between democracy and inequality: increases in democracy reduce inequality. They ground this proposition in Charles Tilly's (2004:128) definition of democratization as movements toward "greater categorical regularity, breadth, equality, binding consultation, and protection," pithily summarizing the relationship as follows: "Democratization is best understood as an expansion in the quality of citizenship, which is about the institutionalized quality of a subject's relation to government and its authority, which in turn exists in inverse proportion to the degree to which a subject's relations to government are mediated by categorical inequalities." As we have stated, Heller and Evans primarily examine the relationship between national and local democracy. But even setting aside the national/local disjunction, there is an evident limitation in using this logic to understand the relationship between democracy and inequality: Tilly, Heller, and Evans incorporate reductions in the impact of inequality into the definition of democratization, which risks rendering the relationship tautological. While this broad 
definition of democracy is satisfying in many ways, it does not tell us much about how a more narrowly defined democracy is likely to affect inequality.

Elisabeth Clemens adds a level of complexity. Her account of the role of business in local US systems of charity demonstrates that democratization of urban politics drove businesses to get involved in charity. But businesses' strategic approach to charity limited the redistributive impact of this shift. Businesses used their involvement in giving to win legitimacy and to control the flow of resources directed toward social problems, forestalling more extensive redistribution that might challenge their interests. In short, the linkage between democracy and inequality is mediated by the strategies of key actors - in this case elites, in other cases social movements.

Diane Davis and Carmenza Gallo point to darker possibilities, emphasizing that even in circumstances of formal democracy, those controlling capital can shortcircuit attempts at equalization by funding coercion independent of the state. As we have noted, Gallo uses the Colombian case to demonstrate that rights to property and even life are harder to ensure than democracy. Although we tend to think of insecurity of property rights as particularly affecting the rich, Gallo notes that Colombia's dissolution of rural property rights has fallen most heavily on the poor, with 1.5 million peasants displaced in the 1990s. Diane Davis limns symmetrical processes at work in countries like Mexico: on the one hand, new accumulations of capital through illicit activities such as drug trafficking, kidnapping, and contraband sales give criminal entrepreneurs the wherewithal to organize paramilitary forces; on the other hand, the wealthy assemble their own private armies to insulate themselves from attack. In both cases, impunity mounts. Davis emphasizes that these corrosive processes are taking place in stable democracies - the degree of democracy is debatable in the case of Mexico, but Brazil meets even Heller and Evans's exacting definition. Democracy does not necessarily offer sufficient tools to curb capital-driven coercion. In the cases Davis examines, such coercion in turn degrades democracy by marginalizing the state, implicating it, or feeding repression and surveillance.

Broadening the frame beyond local and national states to encompass empires additionally complicates matters. Hwa-Ji Shin stretches the democracy-inequality connection still further, turning Heller and Evans (and Charles Tilly) on their heads by exploring a case in which democracy and equality moved in opposite directions. In Japan's shift from pre-World War II empire to postwar parliamentary democracy, Japan's relation to other Asian nationalities morphed from imperialist, exploitative inclusion to democratic exclusion. Democracy set the framework for hardening of categorical inequalities. Miguel Centeno and Elaine Enriquez, also analyzing empires, observe that the United States forged an inclusive democracy out of empire via a genocide that essentially eliminated the original denizens of the country's territoryechoing the construction of citizenship on the basis of mass expulsion of "others" in Salzmann's account of European history. Centeno and Enriquez add that accentuation of inequality between metropole and periphery may underpin reductions in inequality in the parent state. After all, apartheid, one of the most notorious expressions of categorical inequality, resulted from Afrikaners' opportunity-hoarding attempt to overcome their subordinate status within white South African society.

Many of this collection's authors also make a third observation about democracy and inequality: the relationship between the democratic state and inequality is twoedged. The dual nature of the state is not a new idea: Karl Polanyi's (1967) "double 
movement" oscillating between liberalization and regulation and James O'Connor's (1973) twin imperatives of legitimation and accumulation anticipate some of the arguments advanced here. But this group of social scientists and historians offers fresh and forceful formulations of the issue. Michael Katz makes the basic point most directly: asking whether the state is the problem or the solution as regards social equality, he replies that it is both. He couches his discussion in a wry contrast between earlier left critiques of US systems of education, welfare, and urban policy, and more recent left defenses of the same systems in the face of conservative onslaught. The state is both a defender of inequality when compared to more radical alternatives, and an equalizing force when compared to more neoliberal ones. Katz calls on scholars to state more clearly their criteria for "success" or "failure" of government, since different criteria call for distinct responses to failure. He points to the need for scholars on the left to move beyond critiques, which may be harnessed to a conservative anti-government discourse, to a "comprehensive and coherent counter-narrative."

Davis and Gallo's analyses also speak to the two faces of the state. Any social scientist or historian of Latin America must recognize that the state can shore up inequality- the recent history of dictatorships closely tied to economic elites makes a prima facie case. But both articles show how inadequate state capacity and the breakdown of the state's monopoly on organized force can also have dramatically disequalizing effects.

But not all the issue's authors line up behind a dual conception of the state. Peter Marcuse determinedly marches to a different drummer. His article depicts a capitalist state that, despite concessions to social movements, remains committed to defending economic privilege and heading off redistribution. While endorsing struggles for rights and reforms and conceding that opportunities for revolution by means of force are rare to nonexistent, he expresses skepticism about the electoral and policy battles that absorb the attention of many of the other authors.

\section{Concluding remarks}

Charles Tilly will never write his book on "Cities and States in World History," and that loss gives us one more reason to mourn his passing. But as this collection demonstrates, the study of cities, states, and trust networks is in good hands. These articles build on and extend Tilly's analyses geographically and temporally, particularly by addressing the global South. They scrutinize important phenomena to which he devoted little attention, informing us about empires and their aftermath, and about elite trust networks as well as outsider ones. They include challenges to Tillyan generalizations, pitting geohistory against historicism, posing rescaling against a hypothesized trend toward national state dominance, and revealing disjunctions between equalization and democratization pace Tilly's argument about the linkage of the two processes. And they break entirely new ground, surfacing questions, puzzles, and hypotheses about structure and contingency, trust networks, city-state relations, and the interplay between democracy and inequality that, like Tilly's own work, will occupy scholars for generations to come. Charles Tilly would doubtless have responded to this collection with a combination of applause, hard questioning, vociferous counter-argument, and the formulation of new research agendas informed by the essays' insights. We urge our readers to respond similarly. 
Open Access This article is distributed under the terms of the Creative Commons Attribution Noncommercial License which permits any noncommercial use, distribution, and reproduction in any medium, provided the original author(s) and source are credited.

\section{References}

Appadurai, A. (2002). Deep democracy: urban governmentality and the horizon of politics. Public Culture, 14 (1), $21-47$.

Barkey, K. (2008). Empire of difference: The ottomans in comparative perspective. Cambridge: Cambridge University Press.

Centeno, M. A. (2003). Blood and debt: War and the Nation State in Latin America. University Park: Pennsylvania State University Press.

Fagan, B. (1999). Floods, famine, and emperors: El Nino and the fate of civilization. New York: Basic Books. Marx, K. (1910). The Poverty of Philosophy. Chicago: Charles H. Kerr \& Co.

McAdam, D., Tarrow, S., \& Tilly, C. (2001). Dynamics of contention. Cambridge: Cambridge University Press. O'Connor, J. (1973). The fiscal crisis of the state. New York: St. Martin's Press.

Polanyi, K. (1967 [1944]). The great transformation. Boston: Beacon.

Stave, B. M. (1998). A conversation with Charles Tilly: urban history and urban sociology. Journal of Urban History, 24, 184-225.

Tarrow, S. (2004). From comparative historical analysis to 'local theory': the Italian city-state to the modern state. Theory and Society, 33(2004), 443-471.

Thompson, E. P. (1964). The making of the English working class. New York: Pantheon Books.

Tilly, C. (1965). Migration to an American City. Newark: Division of Urban Affairs and School of Agriculture, University of Delaware.

Tilly, C. (1974). An urban world. Boston: Little, Brown.

Tilly, C. (1985). War making and state making as organized crime. In P. Evans, D. Rueschemeyer, \& T. Skocpol (Eds.), Bringing the state back in. Cambridge: Cambridge University Press.

Tilly, C. (1986). The contentious French. Cambridge: Belknap Press of Harvard University Press.

Tilly, C. (1990). Coercion, capital, and European States, A.D. 990-1990. Oxford: Blackwell.

Tilly, C. (1996). What good is urban history? Journal of Urban History, 22, 702-719.

Tilly, C. (1998). Durable inequality. Berkeley: University of California Press.

Tilly, C. (2004). Social movements, 1768-2004. Boulder: Paradigm.

Tilly, C. (2005). Trust and rule. Cambridge: Cambridge University Press.

Tilly, C. (2007). Democracy. Cambridge: Cambridge University Press.

Wallerstein, I. (1974). The modern world-system 1: Capitalist agriculture and the origins of the European world-system in the sixteenth century. New York: Academic.

Michael Hanagan teaches history at Vassar College in Poughkeepsie, New York. He is the author of several books on labor history and has also co-edited a number of books, most recently, Expanding Rights, Reconfiguring States and Challenging Authority: the Historical Study of Contentious Politics. He is currently collaborating on a world history textbook and on a comparative study of the welfare state in England, France, and the United States.

Chris Tilly Professor of Urban Planning and Director of the Institute for Research on Labor and Employment at the University of California Los Angeles, is an economist specializing in labor, income distribution, and local economic development, with research focusing on the United States and Mexico. Tilly's books include Half a Job: Bad and Good Part-Time Jobs in a Changing Labor Market; Glass Ceilings and Bottomless Pits: Women's Work, Women's Poverty; Work Under Capitalism; Stories Employers Tell: Race, Skill, and Hiring in America; and The Gloves-Off Economy: Labor Standards at the Bottom of America's Labor Market. 